\title{
Bacteriological Quality of Water Contaminated with Faecal Wastes from Livestock
}

\author{
Anyadoh-Nwadike S. O. ${ }^{1,}$, Okereke J. N. ${ }^{1}$, Odah R. ${ }^{1}$, Obijekwu O. ${ }^{1}$, Okorondu S. I. ${ }^{2}$, Obasi K. O. ${ }^{1}$ \\ ${ }^{1}$ Department of Biotechnology, Federal University of Technology, Imo State, Nigeria \\ ${ }^{2}$ Department of Microbiology, Federal University of Technology, Imo State, Nigeria
}

\section{Email addresses:}

sylanyad@yahoo.com (Anyadoh-Nwadike S. O.), chinwendubueze1@yahoo.com (Okereke J. N.), sokorondu@yahoo.co.uk (Okorondu, S. I.), kayboy2013@live.com (Obasi K. O.)

\section{To cite this article:}

Anyadoh-Nwadike S. O., Okereke J. N., Odah R., Obijekwu O., Okorondu S. I., Obasi K.O.. Bacteriological Quality of Water Contaminated with Faecal Wastes from Livestock. Science Journal of Public Health.Special Issue: Who Is Afraid of the Microbes.

Vol. 3, No. 5-1, 2015, pp. 29-33. doi: 10.11648/j.sjph.s.2015030501.16

\begin{abstract}
Water is very important to life but when contaminated, it can be deleterious to life. Livestock from various farms produce large amount of faecal wastes. Most cattle farmers move their animals from place to place around Imo State, Nigeria, in search of pasture, these animals defeacate indiscriminately. Again, many farmers indulge in indiscriminate disposal of animal wastes. These faecal wastes can be carried by runoff water into surrounding water sources causing them to become contaminated. This study was therefore carried out to determine the prevalence of possible pathogenic bacteria in water contaminated with poultry litters, cow and pig dungs. Faecal samples from poultry, cows and pigs were collected from School of Agriculture and Agricultural Technology (SAAT) farm in the Federal University of Technology Owerri (FUTO), Imo State, Nigeria. The contaminated water samples were examined for the prevalence of bacteria. Isolation and characterization of bacteria were done using standard microbiological protocols. Results revealed the presence of Escherichia coli, Enterobacter aerogenes, Serratia marcescens, Erwinia amylovora, Vibrio cholerae, Pseudomonas aeruginosa, Citrobacter freundii, Proteus vulgaris, Staphylococcus aureus, Bacillus subtilis, Streptococcus faecalis and Salmonella typhi. Pseudomonas aeruginosa was the most prevalent isolate followed by Escherichia coli and Vibrio cholerae. The presence of these organisms of public health importance in water contaminated by livestock faeces calls for continuous surveillance of various water sources prone to faecal contamination. Appropriate treatment and disposal methods of these faecal samples as well as appropriate treatment of water source prone to such contaminants should be adopted so as to avert the possible health hazards resulting from use of water from such contaminated sources.
\end{abstract}

Keywords: Bacteria, Contaminated Water, Cow Dung, Pig Dung, Poultry Litters

\section{Introduction}

Water covers $71 \%$ of the Earth's surface [1]. It is vital for all known forms of life. Only $2.5 \%$ of the Earth's water is 'freshwater' and $98.8 \%$ of that water is in ice and groundwater. Less than $0.3 \%$ of all freshwater is in rivers, lakes, and the atmosphere, and an even smaller amount of the Earth's freshwater $(0.003 \%)$ is contained within biological bodies and manufactured products [1].Water is our lifeline that bathes us and feeds us. In ancient cultures, water represented the very essence of life. It provides the Earth with the capacity of supporting life [2].

Water pollution is any contamination of water with either chemicals or other foreign substances that are detrimental to human, plant or animal health [3]. These pollutants may include agricultural wastes, fertilizers and pesticides from agricultural runoff, sewage and food processing waste, lead mercury and other heavy metals, chemical contamination from hazardous waste sites as well as domestic wastes. Worldwide nearly two billion people drink water from sources that could be harmful to health [3]. Water pollution affects plants and organisms living in the bodies of water; in most cases the effects get to natural biological communities [4].Consumption of contaminated water has far reaching public health import causing water-borne diseases which include: diarrhoea, typhoid fever, nausea, cholera as well as 
viral infections $[4,5]$.

In Imo State, herdsmen and animal farmers engage in indiscriminate grazing and rearing of their animals. These animals defeacate randomly in different places and their faeces are deposited via run off to the nearest water bodies. Furthermore, when some farmers clean their pens and farms, they as well, deposit the wastes most times without proper treatment into water bodies. Some of these unassuming farmers may not understand the effect of such indiscriminate dumping of animal wastes products.

When faeces from animals such as cow, pig and poultry come in contact with a water source, they contaminate such water source with their inherent microorganisms (most of which are pathogenic). Such contaminated water if ingested by an individual, can cause high health risk to such individual. Some of these bacteria for example include some strains of Escherichia coli which causes diarrhoea and stomach cramp [6]. Pseudomonas aeruginosa [7], Vibrio cholerae which causes cholera and Salmonella typhi which causes typhoid fever[8]. Animal wastes just like other substances such as sewage and agricultural wastes are usually high in organic matter and nutrient. Hence they could cause increase in the microbial flora of the water bodies, thereby resulting in high heterotrophic bacteria counts [9].

Aim of study: This study was carried out in order to identify and characterize possible pathogenic bacteria present in water contaminated with poultry litters, cow and pig dung with a view to creating awareness of the existence of such pathogenic organisms in livestock faeces and their public health importance.

\section{Methodology}

\subsection{Sample Collection and Preparation}

Faecal samples from cow, pig and poultry were collected from SAAT farm, located in Federal University of Technology, Owerri West Local Government Area of Imo State. These were carefully put inside appropriately labeled sterile whirl packs and carried to the laboratory for further use.

Twenty eight and half grams of each sample were put into well labeled sterile containers and Six hundred milliliter (600 $\mathrm{ml}$ ) of sterile water was poured into the containers habouring the faecal samples, giving a value of $47.5 \mathrm{mg} / \mathrm{l}$.

The labeling of the containers was done according to the respective faecal samples used as follows:
Label:
Faecal sample
A:
Cow dung
B: $\quad$ Poultry litters
C: $\quad$ Pig dung
D: $\quad$ Control (sterile water)

The contaminated water samples were then left for 7days to allow/encourage bacterial growth, before the bacteriological analysis commenced.

\subsection{Isolation and Characterization of Microorganisms}

All glasswares, media and diluents used for culture were sterilized by autoclaving at $121^{\circ} \mathrm{C}$ for 15 minutes at $15 \mathrm{psi}$, while wire loops were sterilized by flaming as recommended by [10].

The respective samples (contaminated water) were thoroughly homogenized, and $1 \mathrm{ml}$ of each was introduced into a sterile test tube containing $9 \mathrm{ml}$ sterile water using a sterile glass pipette. A ten- fold serial dilution was then carried on each sample

Aliquots $(0.1 \mathrm{ml})$ of three different dilutions $\left(10^{-3}, 10^{-5}\right.$ and $10^{-6}$ ) of each sample were inoculated on the respective agar plates by the pour plate method as described by [10] these were then incubated at $37^{\circ} \mathrm{C}$ for 24 hours.

After incubation, colonies observed on different plates, were noted. The morphological characteristics of the isolates were also recorded.

\subsection{Isolation of Pure Culture}

Sub-culturing of observed colonies was done onto sterile nutrient agar plates. The streaking technique was employed to obtain pure cultures prior to characterization/ identification of the isolates.

\subsection{Identification of Bacterial Isolates}

Bacteria isolated from the samples were characterized based on the colonial, morphological, standard microbiological and biochemical reactions of the pure cultures as described by [10].

The following biochemical tests were carried out: motility, indole, methyl red, catalase, voges proskauer, coagulase, oxidase and sugar fermentation tests. These tests were carried out in order to confirm the identities of the bacteria isolated. The results obtained from biochemical tests were cross matched with the Bergey's manual of determinative bacteriology [5].

\section{Results}

Table 1 shows the characteristics of different microbial isolates from the respective faecally contaminated water samples labeled A - C and a control labeled D.

\section{Discussion and Conclusion}

\subsection{Discussion}

Results from this study revealed a total of 19 isolates including both Gram negative and Gram positive bacteria. Characterization of the bacterial isolates revealed twelve species (Table 1). Singleton [11] has reported similar species in water contaminated with livestock waste. The presence of these organisms in water is of public health concern because some of these organisms are considered pathogenic. The public health importance of these organisms are highlighted below. 
Table 1. Characterization/Identification of bacterial isolates from the three different faecal contaminated water samples and control.

\begin{tabular}{|c|c|c|c|c|c|c|c|c|c|c|c|c|c|}
\hline $\begin{array}{l}\text { Samp } \\
\text { les }\end{array}$ & Isolates & $\begin{array}{l}\text { Morphological } \\
\text { characteristics on } \\
\text { nutrient agar }\end{array}$ & $\begin{array}{l}\text { Gram } \\
\text { reaction }\end{array}$ & Motility & Indole & Methyl red & Catalase & Glucose & Lactose & Oxidase & Coagulase & $\begin{array}{l}\text { Voges } \\
\text { Proskauer }\end{array}$ & $\begin{array}{l}\text { Probable } \\
\text { organism }\end{array}$ \\
\hline \multirow{5}{*}{ A } & A1 & $\begin{array}{l}\text { Round, cream } \\
\text { colonies }\end{array}$ & -ve rods & + & - & - & + & + & + & - & - & + & $\begin{array}{l}\text { Enterobacter } \\
\text { aerogenes }\end{array}$ \\
\hline & $\mathrm{A} 2$ & $\begin{array}{l}\text { Clustered creamy } \\
\text { colonies }\end{array}$ & $\begin{array}{l}\text { +ve cocci } \\
\text { in } \\
\text { clusters }\end{array}$ & - & - & + & + & + & + & - & + & - & $\begin{array}{l}\text { Staphylococcus } \\
\text { aureus }\end{array}$ \\
\hline & A3 & $\begin{array}{l}\text { Smooth, raised, } \\
\text { cream colonies }\end{array}$ & -ve rods & + & + & + & + & + & + & - & - & - & $\begin{array}{l}\text { Escherichia } \\
\text { coli }\end{array}$ \\
\hline & A4 & $\begin{array}{l}\text { Circular, reddish } \\
\text { colonies }\end{array}$ & -ve rods & + & - & - & + & + & - & - & - & + & $\begin{array}{l}\text { Serratia } \\
\text { marcesens }\end{array}$ \\
\hline & A5 & $\begin{array}{l}\text { Circular grey } \\
\text { colonies }\end{array}$ & -ve rods & + & + & + & + & + & - & - & - & - & $\begin{array}{l}\text { Erwinia } \\
\text { amylovora }\end{array}$ \\
\hline \multirow{5}{*}{ B } & A6 & $\begin{array}{l}\text { Round creamy } \\
\text { colonies }\end{array}$ & -ve rods & + & - & - & + & + & + & - & - & + & $\begin{array}{l}\text { Enterobacter } \\
\text { aerogenes }\end{array}$ \\
\hline & B1 & $\begin{array}{l}\text { Circular, yellowish } \\
\text { colonies }\end{array}$ & $\begin{array}{l}\text {-ve } \\
\text { curved } \\
\text { rods }\end{array}$ & + & + & + & + & + & - & + & - & - & Vibrio cholerae \\
\hline & B2 & $\begin{array}{l}\text { Circular, mucoid } \\
\text { smooth, greenish }\end{array}$ & -ve rods & + & - & + & + & - & - & + & - & - & $\begin{array}{l}\text { Pseudomonas } \\
\text { aeruginosa }\end{array}$ \\
\hline & B3 & $\begin{array}{l}\text { Circular, mucoid } \\
\text { smooth, greenish }\end{array}$ & -ve rods & + & - & + & + & - & - & + & - & - & $\begin{array}{l}\text { Pseudomonas } \\
\text { aeruginosa }\end{array}$ \\
\hline & B4 & $\begin{array}{l}\text { Circular, mucoid, } \\
\text { smooth, greenish }\end{array}$ & -ve rods & + & - & + & + & - & - & + & - & - & $\begin{array}{l}\text { Pseudomonas } \\
\text { aeruginosa }\end{array}$ \\
\hline \multirow{9}{*}{$\mathrm{C}$} & B5 & $\begin{array}{l}\text { Creamy, flat } \\
\text { colonies }\end{array}$ & +ve rods & + & - & + & + & + & + & - & + & - & $\begin{array}{l}\text { Bacillus } \\
\text { subtilis }\end{array}$ \\
\hline & B6 & $\begin{array}{l}\text { Round creamy } \\
\text { colonies }\end{array}$ & -ve rods & + & - & + & + & + & + & - & - & - & $\begin{array}{l}\text { Citrobacter } \\
\text { freundii }\end{array}$ \\
\hline & $\mathrm{C} 1$ & $\begin{array}{l}\text { Circular, mucoid, } \\
\text { smooth, greenish }\end{array}$ & -ve rods & + & - & + & + & - & - & + & - & - & $\begin{array}{l}\text { Pseudomonas } \\
\text { aeruginosa }\end{array}$ \\
\hline & $\mathrm{C} 2$ & $\begin{array}{l}\text { Circular, mucoid } \\
\text { smooth, greenish }\end{array}$ & -ve rods & + & - & + & + & - & - & + & - & - & $\begin{array}{l}\text { Pseudomonas } \\
\text { aeruginosa }\end{array}$ \\
\hline & $\mathrm{C} 3$ & $\begin{array}{l}\text { Mucoid, yellow } \\
\text { coloured, small }\end{array}$ & $\begin{array}{l}\text { +ve cocci } \\
\text { in short } \\
\text { chains }\end{array}$ & & - & - & - & + & + & - & + & - & $\begin{array}{l}\text { Enterococcus } \\
\text { faecalis }\end{array}$ \\
\hline & $\mathrm{C} 4$ & $\begin{array}{l}\text { Round, swarming, } \\
\text { cream, flat }\end{array}$ & -ve rods & + & + & + & - & + & - & - & - & - & $\begin{array}{l}\text { Proteus } \\
\text { vulgaris }\end{array}$ \\
\hline & C5 & Circular, yellowish & -ve rods & + & + & + & + & + & - & + & - & - & Vibrio cholerae \\
\hline & $\mathrm{C} 6$ & $\begin{array}{l}\text { Grey, raised, } \\
\text { smooth }\end{array}$ & -ve rods & + & + & + & + & + & + & - & - & - & $\begin{array}{l}\text { Escherichia } \\
\text { coli }\end{array}$ \\
\hline & $\mathrm{C} 7$ & $\begin{array}{l}\text { Cream, round, } \\
\text { raised mucoid } \\
\text { colonies in chains }\end{array}$ & -ve rods & + & - & + & + & + & -- & - & - & - & $\begin{array}{l}\text { Salmonella } \\
\text { typhi }\end{array}$ \\
\hline D & $\mathrm{NG}$ & $\begin{array}{l}\text { No observable } \\
\text { growth }\end{array}$ & & & & & & & & & & & NG \\
\hline
\end{tabular}

Key: - ve $=$ Negative, + ve $=$ Positive, $\mathrm{NG}=$ No observable growth.

Escherichia coli are a large group of bacteria that can infect someone via ingestion of contaminated water. Most strains of $E$. coli are harmless, however some strains such as E. coli $0157: \mathrm{H} 7$ produce a toxin that can cause diseases like diarrhea (often with blood) and stomach cramps. Serious complication of E. coli $0157: \mathrm{H} 7$ infection is hemolytic uremic syndrome (kidney failure) [6, 8].

Enterobacter aerogenes are called opportunistic pathogens, they can cause numerous infections to humans such as cerebral abscesses, pneumonia, meningitis and septicaemia. This bacterium can infect someone who drinks water contaminated by it $[8,12]$.

Serratia marcescens are pathogenic bacteria responsible for a variety of infection which includes bacteraemia and intravenous catheter associated infections $(10,12)$.

Erwinia amylovora are plant pathogenic bacteria that infect plant (such as pear and apple) and cause the disease "fire blight" to them. They can be infected when they come in contact with faecally contaminated water either through groundwater uptake or through runoff water.

Vibrio cholerae is a human pathogenic bacterium that causes cholera. Cholera is a major public health problem 
confronting developing countries. It is associated with poverty and poor sanitation. This disease is characterized by devastating watery diarrhoea and leads to dehydration and sometimes death $[8,9,10]$. It is associated with epidemics and pandemics [10].

Pseudomonas aeruginosa is an opportunistic pathogen, it is called opportunistic because it affects immunocompromised hosts (e.g HIV/AIDS, cystic fibrosis and diabetes mellitus). The common site of infection is the lower respiratory tract [10].

Citrobacter freundii is an opportunistic nosocomial pathogen that can cause urinary tract infections, blood stream infection and neonatal meningitis that can lead to brain abscesses [11, 13].

Proteus vulgaris has been associated with urinary tract infection such as urolithiasis (stone formation in the kidney or bladder) [12].

Salmonella typhi is a bacterium that causes typhoid fever. This disease is characterized by the sudden onset of a sustained and systematic fever, severe headache, nausea, loss of appetite, diarrhoea and possible development of meningitis. Untreated typhoid fever can result to death [14].

Staphylococcus aureus is a common member of the human micro flora, it can however, produce diseases of adverse health effect $[5,10,15]$ such as skin sepsis, post operative wound infections, enteric infections and many more $[5,10]$. It is relatively spread in the environment, but found mainly on the skin and mucus membranes of animals. It has also been detected in sewage and in drinking water supplies [15].

Enterococcus faecalis formerly known as Streptococcus faecalis are faculatively anaerobic, catalase-negative, Gram positive cocci. They are normal inhabitants of the intestinal tract of animals and their oral cavity [5, 10]. They are consistently the second or third most common agent in urinary tract infections, wound infections, and bacterial infections [10]. The hosts for this bacterium include human, pets and livestock [16].

Bacillus subtilis is an endospore forming bacterium. The endospore allows it to withstand extreme temperatures. Therefore water contaminated by livestock waste will require a proper treatment to make the water fit for drinking and other purposes. However, this bacterium is not considered strictly pathogenic [17].

Pseudomonas aeruginosa was the most prevalent organism followed by Escherichia coli and Vibrio cholerae each being found in at least two of the faecally contaminated sample. The contamination of water by these bacteria is worrisome: The presence of Escherichia coli in water not only pose problem of being pathogenic but also indicates the presence of other pathogenic organisms in such water body because it is a known "indicator organism"[18]. Vibrio cholerae on its own is a very versatile epidemic causing organism especially among children $[8,9,10]$. Pseudomonas aeruginosa is a known recalcitrant organism [8].

\subsection{Conclusion}

Based on the findings of this study, it is evident that, contamination of water with livestock waste can lead to introduction of various types of bacteria of public health importance. These can easily be transferred to man and even his livestock via consumption, wadding and bathing activities.

There is therefore need for deliberate policies and laws by the government to restrict illegal dumping of faecal waste from livestock farms into water sources. Public awareness in form of workshops should be organized for livestock farmers and indeed the entire community around such environment to educate them on the importance of water sanitation and good faecal waste disposal methods. Livestock farmers should be assisted via incentives which can help manage livestock waste and this management process should be supervised by waste management experts.

Closed grazing system where the livestock waste products are utilized within the system and does not portend a burden to the environment and water sources around the environment should be adopted by livestock farmers. Furthermore livestock farms should have improved hygiene standard within and around their environment. These will in turn help to alleviate pollution of the environment especially water resources around such areas thereby conserving the water that the populace that uses it for sundry activities.

\section{References}

[1] P.H. Gleick, Water in Crisis: A guide to the world's freshwater resources. Oxford University Press: London. 1993, Pp 13-15.

[2] T. Ayres, "The importance of water in life," Journal of water and life, 2008 vol. 6, 52-60.

[3] J. Alder and R.U. Sumailia, "Western Africa, A fish basket of Europe past and present," Journal of environment and development 2004 vol. 12:156-178.

[4] T. W. Hejkal, B. Koswick, R. L. Labolle, C. P. Gorba, V. Sanchez, G. Droesman, B. Hafkin and J.L. Meinick, "Viruses in a community water supply associated with an outbreak of gastroenteritis and infectious hepatitis," Journal of the American water association, 1982, vol. 14, Pp. $317-321$.

[5] D.H. Bergey and J.G. Holt, Bergey's manual of determinative bacteriology, 9th ed. Williams and Wilkins: Baltimore, 1994.

[6] R.L. Vogt and O.C. Dippold, "Escherichia coli 0157:H7 outbreak associated with consumption of contaminated water," Medical microbiology, 2005, vol. 5:78-84.

[7] P.V. Liu and C.B. Mercer, "Growth toxigenicity and virulence of Pseudomonas aeruginosa," The Journal of hygiene, 2003, vol. 61:485-491.

[8] K.J. Ryan and C.J. Ray, "An introduction to infectious diseases," Journal of Medical Microbiology, 2004, vol. 4:6269.

[9] C.O. Owuama and A. P. Uzoije, "Waste disposal and Ground Water quality in Owerri," Nigeria Journal of Environmental systems, 2005, vol. 31(1) Pp. 69 - 79.

[10] M. Cheesbrough, District laboratory practice in tropical countries; Part 2, Cambridge University Press: UK, 2000. 
[11] P. Singleton, "Bacteria in biology," Journal of biotechnology and medicine, 2004, vol. 4:444:454.

[12] C.A. Hart, "Klebsiella, Citrobacter, Enterobacter and Serratia spp. In: principles and practice of clinical bacteriology (Gillespie S.H and Hawkey P.M. eds.), John Wiley and sons limited England, United Kingdom, 2006, Chp. 2:377-386.

[13] T.I. Doran, 'The role of Citrobacter freundii in clinical disease of children," Clinical infectious diseases, 1999, vol. 21:384394.

[14] J.A. Cason, N.A. Cox and J.S. Bailey, "Transmission of Salmonella typhi in livestock environment," Journal of the science of food and agriculture, 1994; 88:714-719.
[15] S.P. Antai, "Incidence of Staphylococcus aureus and coliform in rural water supplies in Port Harcourt," Journal of applied bacteriology, 1978, vol. 62:37-375.

[16] M.M. Huycke, M. Sahm and M.S. Gilmore, "Multiple drug resistant enterococci: The nature of the problem and an Agenda for the future," Emerging infection diseases, 1998, vol. 4:239-249.

[17] S.L. Nakano, W.M. Michiko and P.S. Zuber, "Anaerobic growth of a strict aerobe (Bacillus subtilis)," Annual review of microbiology, 1998, vol. 52; 165-190.

[18] M.N. Paul, "Pathogenic basics," Journal of livestock and poultry environment, 2004, vol. 5:70-74. 